\title{
THE VALUE OF E-PROCUREMENT MODELS IN B2B EXCHANGES - AN AUSTRALIAN EXPERIENCE
}

\author{
DOUGLAS THOMSON and MOHINI SINGH \\ School of Business Information Technology, RMIT University, Australia
}

\begin{abstract}
This paper presents a theoretical e-procurement model that was developed for a large multinational Australian corporate as a business plan as the company moves from traditional paper and EDI based processes to e-procurement. The model provides a framework for optimising e-procurement processes while enhancing interrelationships between buyers and sellers. The multidisciplinary framework is based on value propositions specific to a single corporate, or to a buyer consortium using e-markets to facilitate B2B exchanges. The e-markets that facilitated the B2B exchanges or that were set up to facilitate the B2B exchanges comprised many founding shareholder enterprises, some of whom are both buyers and sellers in the B2B exchange arena. The impact of the model on e-procurement, the role of e-markets and resulting issues after implementation are discussed in this paper. The values of e-procurement models in $\mathrm{B} 2 \mathrm{~B}$ exchanges have also been highlighted. The model presented in this paper provides the framework for optimising these systems and processes and their relationships using e-enablement of the procurement process.
\end{abstract}

\section{INTRODUCTION}

Corporates around the world are implementing e-business, and are looking for guidance as to how this may be best achieved. Australian businesses have variously considered the adoption of the Internet as a pervasive tool for communication, research and as a medium of business. These changes have created competitive global pressures which are intense, but are aided by an improved ability to cope with complexity through use of

The original version of this chapter was revised: The copyright line was incorrect. This has been corrected. The Erratum to this chapter is available at DOI: 10.1007/978-0-387-35692-1_36 
the enabling Internet based technology. This growth in competition can be explained by the confluence of new technology with old needs

\section{INPACT OF THF. INTERNET ON BUSIN}

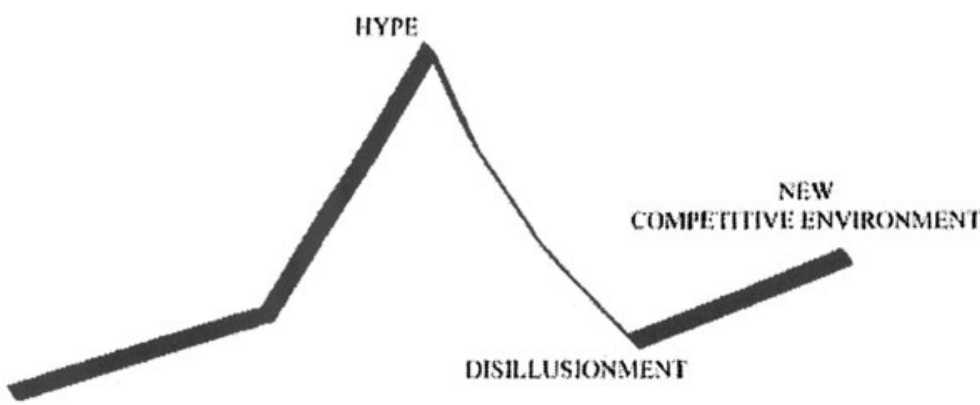

(Kinney, 2000).

B2B e-commerce in Australia is in a state of evolution as firms become accustomed to doing business electronically. With an increased emphasis on e-procurement as an accepted B2B e-commerce application, Australia has seen a proliferation of third party e-markets facilitating e-procurement. These e-markets are both consortia based as well as private. More recently however, consolidation of e-markets has taken place due to high operating costs and lengthy implementation time, the need for effective revenue models and the need to continuously adapt to new business models.

The Australian Bureau of Statistics Report on Business Use of Information Technology (2000) indicates that from June 1998 to June 2000 the proportion of Australian businesses accessing the Internet increased from 29 percent to 56 percent, while those with a web site increased from 6 percent to 16 percent. Australian companies using and developing Internet business tools generated revenues of 28 billion dollars in 2000 and 2001, which represents around 4.3 per cent of Australia's GDP. Use of ecommerce in Australia is becoming widespread. The Australian National Office for the Information Economy (NOIE) Report (2001) states that 55\% of the firms surveyed indicated that they had complemented their traditional business activities with e-commerce, and $62 \%$ realised some cost savings and greater efficiencies. Some B2B e-commerce in Australia developed from B2C e-commerce applications beginning with sell-side capabilities such as providing buyers with product and service information and allowing buyers to place orders online. Some B2C best practices such as searchable online 
catalogues and shopping cart functions are implemented as B2B sell-side transactional capabilities, with online access to fulfilment data, informing the customer of expected shipping date, delivery date and shipping status provided either by the seller or a third party logistics provider. With the developments in $\mathrm{B} 2 \mathrm{~B}$ e-commerce, Web-based e-procurement is the most important application by both large business organizations and governments in Australia. E-procurement benefits include achievement of volume purchases, wider choice of buyers and suppliers, lower costs, better product quality, improved delivery, and reduced paperwork and administrative costs.

\section{LITERATURE REVIEW}

E-procurement is the electronic integration and management of all procurement activities including purchase request, authorisation, ordering, delivery and payment between a purchaser and a supplier (Chaffey, 2002). Rayport and Jaworski (2002) refer to e-procurement as a B2B e-commerce application with Web-based functions that allow employees of a buying organization to purchase goods and services and allow suppliers to manage and communicate the fulfilment of the purchase orders submitted. This includes catalogue management, requisition, control and approval, receiving and exception processing, and financials and payment processing. Thomson and Singh (2001) advocate that e-procurement processes include sourcing of buyers and sellers, a digital catalogue of products, online bidding, ordering, payments, goods dispatch notices (fulfilment), logistics and supply chain management.

Businesses buy a diverse set of products and services, ranging from paper clips to computer systems, from steel to machinery. At the broadest level these purchases have been classified by Kaplan et. al. (2000) into manufacturing inputs and operating inputs. Manufacturing inputs are raw materials and components that go directly into the manufactured product or manufacturing process. Manufacturing inputs tend to be 'vertical' in nature, because the finished products they go into are industry specific. They are sourced from industry specific suppliers and distributors, and they require specialised logistics and fulfilment mechanisms. Operating inputs include indirect materials and services that do not go into finished products. These are sometimes called MRO (Maintenance, Repair and Operating) inputs which include industrial supplies, capital equipment, services and travel related goods. With the exception of capital equipment and some industrial supplies operating inputs are generally classified as 'horizontal'. 
An 'e-marketplace' is a platform for collaboration between buyers and sellers (Matthewson, 2001). The benefits of e-Marketplaces suggested by many include significant cost reductions through process integration; faster channels of communication, reducing order-to-delivery lead times; costeffective identification of new suppliers, products and services; greater price transparency for both buyers and sellers; increased reach and larger customer bases, plus lower acquisition costs for new customers; statistical reports on market activity, creating more accurate forecasts and better responsiveness to changing conditions; elimination of inefficient purchasing procedures; reduction of anti-competitive practices and industry cartels; improved staff productivity, by allowing them to concentrate on key relationships outside the marketplace environment (Matthewson, 2001).

An 'e-market' functions as a trusted intermediary whose well-integrated business procedures and technology save costs and streamline the purchasing and sales processes (Swedish Trade Council, 2001). In the year 2000, e-Markets proliferated at an astounding rate because of the increased potential for adoption of e-procurement in the global B2B e-space. For buyers, e-markets can lower purchasing costs while reaching new suppliers. For suppliers e-markets can lower sales costs and can help the supplier reach new customers (Chaffey, 2002). The large amount of bid, order and transaction management for B2B procurement requires assistance from emarkets (Thomson and Singh, 2001). The most important intermediary in B2B exchanges are e-markets. E-markets support e-procurement by enabling efficiency gains from better pricing of goods and services, cost savings in the administration of procurement processes, consolidation of buyers' sub entities into a single buying unit, and reduced costs through purchasing aggregation for some items. Other intangible benefits include improvements in operations support, employee productivity, visible purchasing habits of business partners and supplier performance. Reduction in procure to pay cycle time, streamlined procurement operations, avoidance of costs associated with outsourcing procurement, and cost savings in invoicing, financing, goods insurance, and delivery are achieved (McGagh, 2000). Emarkets help suppliers by lowering administrative costs; use standard catalogues which can be quickly updated; effectively target and access a wider range of buyers; and lower inventory and warehousing costs (McGagh, 2000). Other opportunities include lower marketing, selling and service costs, an expanded product and service offerings, improved cash flow through improved inventory turns and accounts receivables, pull versus push orientation with buyer organisations, a more detailed insight into a buyer's purchasing needs, and immediate responsiveness to a buyer's needs and virtual product or service bundling (McGagh, 2000). By facilitating eprocurement, e-markets can collect revenue from transactions and associated 
services. Revenue model options include charging a percentage or flat rate on each transaction, annual subscriptions, levees, payment for services and so on.

For each e-market participant, benefits vary according to the participant's position. As buyers go to the e-marketplace for e- procurement, suppliers may not have any choice but to join in. Most suppliers are also potential buyers, therefore the net effect is an increasing participation in e-enabled procurement. Systematic sourcing and spot sourcing of goods and services dominate business purchases and are based on corporate strategic marketplace servicing decisions. Systematic buying through negotiated contracts with pre-qualified suppliers is often relationship oriented and contracts are longer term, usually of the order of one to three years. Spot sourcing is fulfilment of an immediate need, typically of a commoditised item for which it is less important to pre-qualify the suppliers and by relying on a known, standard product (Thomson and Singh, (2001), Chaffey, (2002), and Christiaanse, et al (2001)).

\section{PROPOSED E-PROCUREMENT MODEL}

The proposed e-procurement model covers business buy-do-sell processes i.e. the technology for procure to pay, the transaction marketplace, and the value/supply chain as shown in Figure 1: 


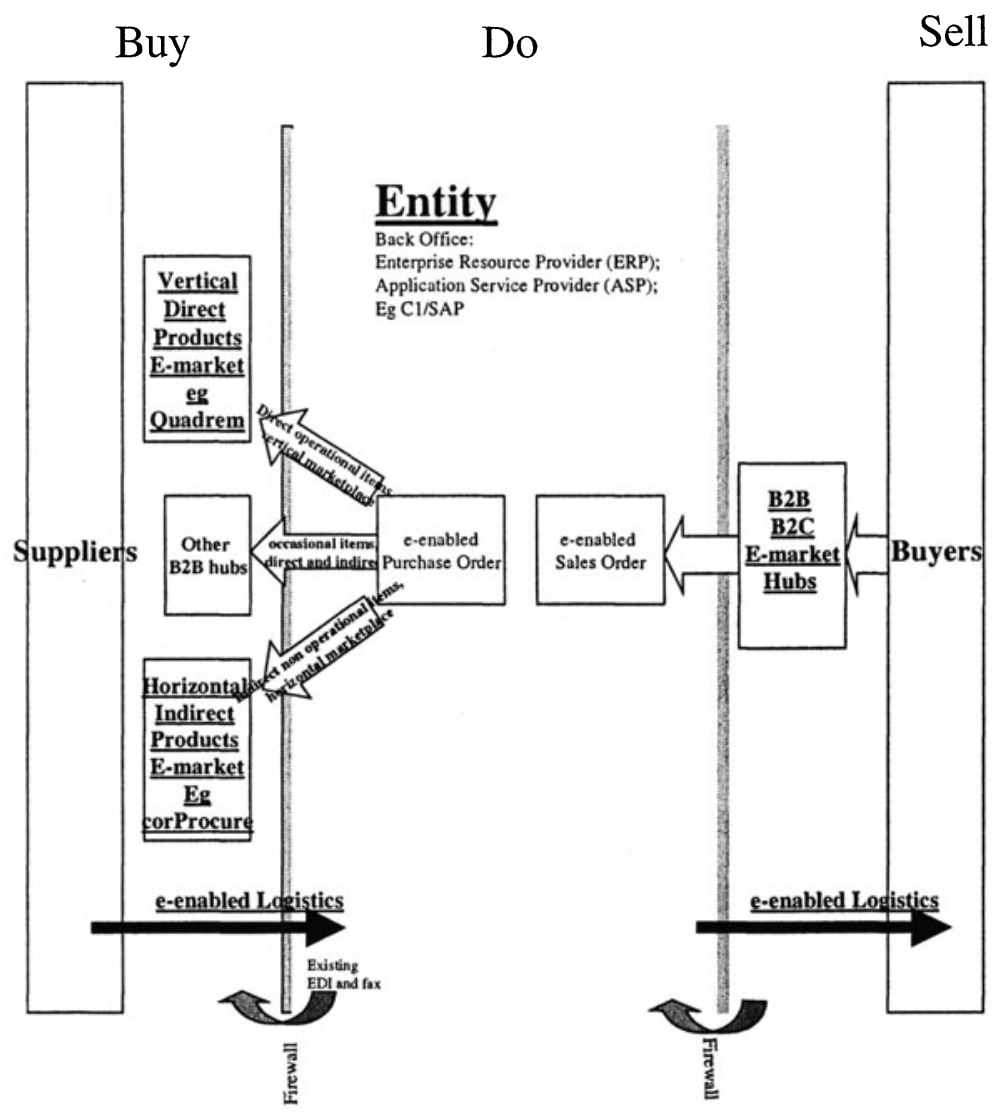

Figure 1. The E-procurement Business Environment End-to-End Process: Buyer to Supplier

The above diagram illustrates the plan for e-enabled procurement using the Internet. It was developed as an initial plan for an Australia based global corporate, BHP Pty Ltd. A more detailed process plan (below) shows the complex atypical e-procurement steps, which are in numbered sequence. 


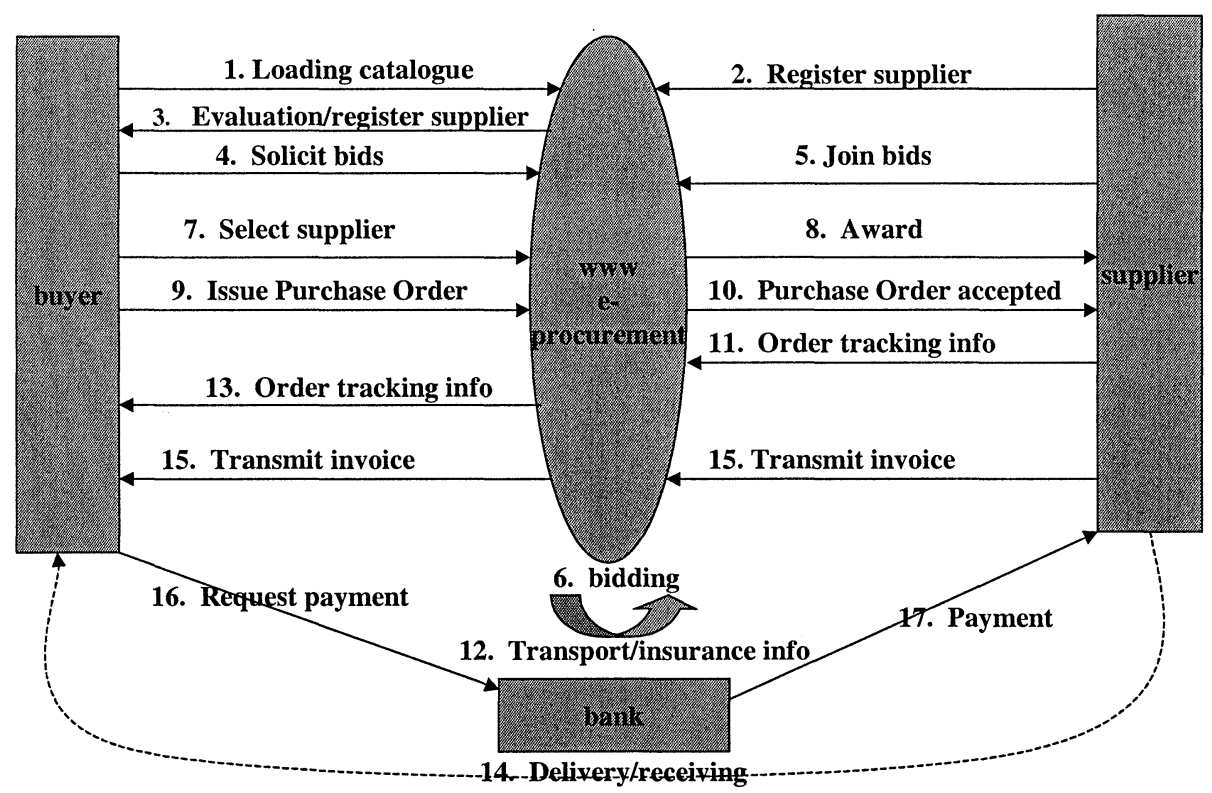

Figure 2. A typical E-procurement process

\subsection{Theoretical Business Model for E-procurement}

This theoretical business model (Figure 3) was developed as a business plan for e-procurement for BHP, a large Australian multi national organization. The model is based on the three major multi-disciplinary dimensions of e-enabled procurement: firstly, e-enabled marketplaces for buying and selling; secondly, e-enabled supply chain/value chain logistics for timely, cost effective delivery; and thirdly, e-enabled technology for procure to pay processes and the interrelationships between these processes. 


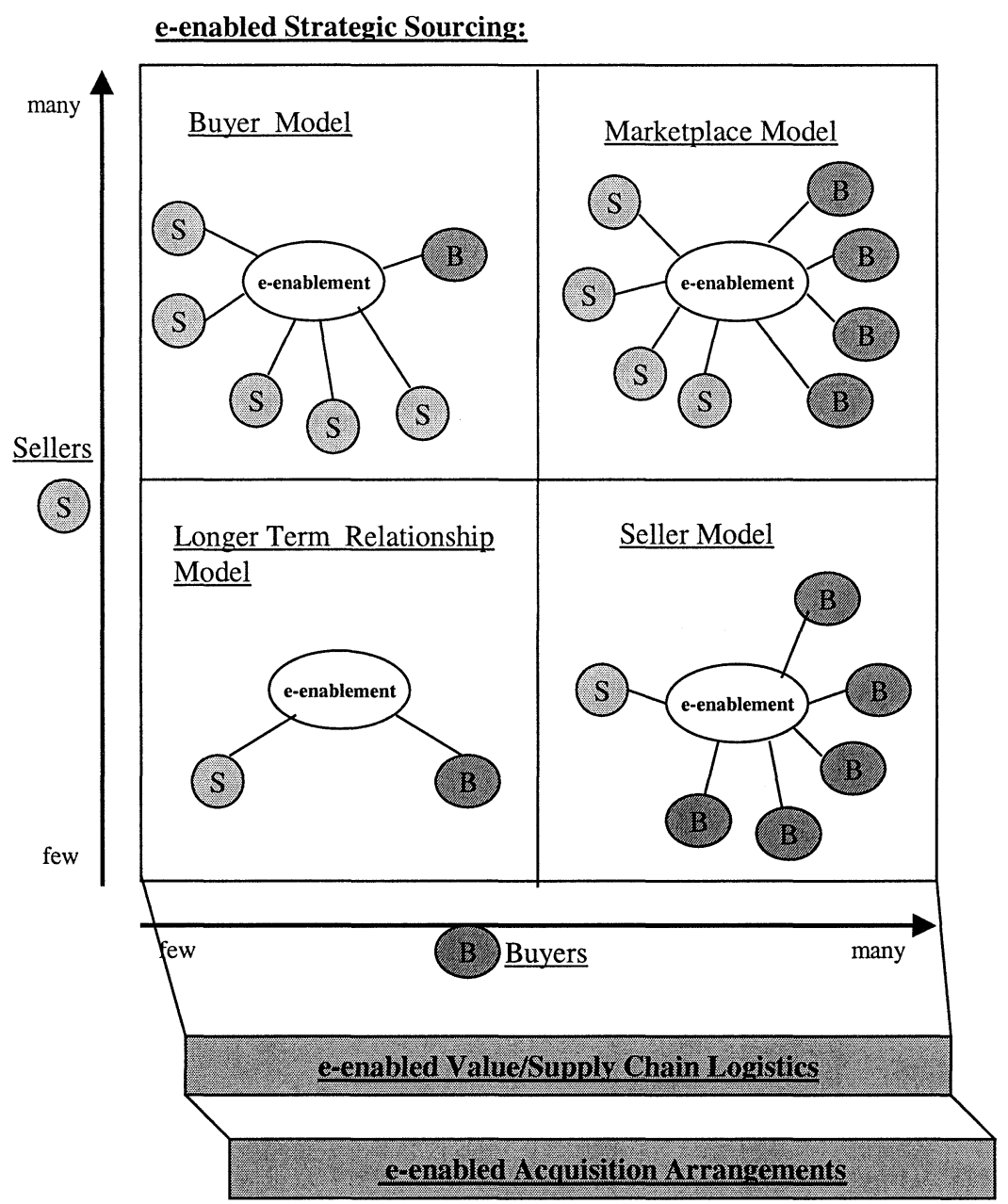

Figure 3. Theoretical Business Model for E-enabled Procurement

Product demand and supply arrangements are often based on high volume low value items and low volume high value items in the approximate proportions 80:20. For example, typical spend across two financial years by the Australian Department of Defence is shown in the following Table 1 (Thomson, 1997):

Australian Department of Defence's actual spread of spend and the number of associated transactions for two Financial Years: 

Australian Experience

\begin{tabular}{|l|l|l|l|l|}
\hline $\begin{array}{l}\text { Value } \\
\text { Bracket of } \\
\text { Procurements }\end{array}$ & $\begin{array}{l}\text { FY } 1 \\
\text { No of } \\
\text { Transactions }\end{array}$ & $\begin{array}{l}\text { FY 1 } \\
\text { Value } \\
(\$ \mathrm{~m})\end{array}$ & $\begin{array}{l}\text { FY 2 } \\
\text { No of transactions }\end{array}$ & $\begin{array}{l}\text { FY 2 } \\
\text { Value } \\
(\$ \mathrm{~m})\end{array}$ \\
\hline$\$ 150 \mathrm{~m}$ and over & 4 & 1404 & 2 & 1515 \\
\hline$\$ 100 \mathrm{~m}$ to $\$ 150 \mathrm{~m}$ & & & & \\
\hline$\$ 50 \mathrm{~m}$ to $\$ 100 \mathrm{~m}$ & 3 & 178 & 4 & 306 \\
\hline$\$ 20 \mathrm{~m}$ to $\$ 50 \mathrm{~m}$ & 7 & 195 & 6 & 187 \\
\hline$\$ 10 \mathrm{~m}$ to $\$ 20 \mathrm{~m}$ & 18 & 241 & 12 & 177 \\
\hline$\$ 5 \mathrm{~m}$ to $\$ 10 \mathrm{~m}$ & 28 & 191 & 28 & 197 \\
\hline$\$ 1 \mathrm{~m}$ to $\$ 5 \mathrm{~m}$ & 193 & 395 & 253 & 549 \\
\hline$\$ 100 \mathrm{k}$ to $\$ 1 \mathrm{~m}$ & 2221 & 590 & 2205 & 583 \\
\hline$\$ 30 \mathrm{k}$ to $\$ 100 \mathrm{k}$ & 4746 & 250 & 4410 & 231 \\
\hline$\$ 2 \mathrm{k}$ to $\$ 30 \mathrm{k}$ & 43769 & 327 & 42035 & 309 \\
\hline & & & & \\
\hline Total & 50989 & 3768 & 48955 & 4054 \\
\hline
\end{tabular}

Table 1

Source: Thomson, JD (1997) 'Purchasing Statistics Bulletin 1989/90 to 1995/96', pp7, Department of Defence, Canberra, February.

This shows that there are typically relatively few high value items but many low value items. For e-procurement and e-markets, this leads to market and product structuring and differentiation. Typically, this may be demonstrated as follows:

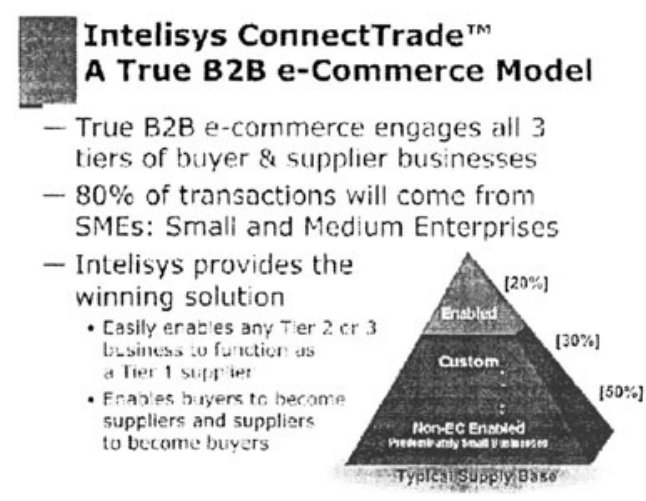

Figure 4. B2B E-commerce Model

The pyramid in Figure 4 shows how this can be translated to the B2B marketplace. Reflecting this and the demand/supply relationships, each quadrant in the e-marketplace model has its own particular application, the knowledge of which will enable product placement based on selected value drivers. For example, low value high volume products will more likely be in 
the 'marketplace quadrant', while high value low volume items are more likely to be in the 'longer term relationship' quadrant. The four quadrants of the model and their relationship with the e-supply/value chain and eacquisition/technology arrangements are briefly explained in the following sections, followed by case studies to demonstrate the model.

\subsection{Marketplace Quadrant (many buyers and sellers)}

The Marketplace Quadrant is appropriate where additional value may be created through third party mediation of the matching process between buyers and sellers, or through aggregation of buying or selling volumes. This quadrant is particularly appropriate for low value high volume products, spot buying and sourcing in cross industries (horizontal) and within industry (vertical) markets for non-core (indirect) business products (Kaplan, 2000).

The value proposition for buyers and sellers is that aggregation reduces transaction, search and marketing costs and mediation improves supply/demand matching. In this quadrant revenue generation potential for e-markets is expected to be high. This quadrant is strategically complex because of existing alliances, contracts, and supply/value chains in the Australian B2B exchange arena.. The focus is on the price of undifferentiated product. This tends to ignore the repercussions of supply/value chain issues, 'value for money' tender selection and the need for smoothly functioning new technology and skills to connect buyers, suppliers and if involved, e-markets.

This quadrant in the model was important for BHP for the purpose of procuring families of largely undifferentiated products commodities such as stationery, or standard service requirements such as catering and cleaning. It also supports indirect spot purchases. Commodities are catalogued and presented in some detail by sellers, and industry specific catalogue items are easily provided in detail, such as assemblies, sub assemblies, components, etc.

\subsection{Buyer Quadrant (few Buyers, many Sellers)}

The buyer quadrant is appropriate in cases where there are a large number of potential sellers and this may result in multiple or fragmented formats, where the buyer is able to leverage buying power through the use of say, reverse auction tools. A reverse auction is where a supplier's winning bid is the lowest, rather than the highest, so suppliers compete against each other through an auction process to win the auction by making the lowest bid. Buyers can demand supply through these processes, so forcing the many 
suppliers to comply with the buyer's e-technology, requirements and processes.

The value proposition for the one or few buyers, in this case BHP, is that they can demand a common format for all electronic applications, specifications and contracts across all sellers; enforce compliance through workflow and supply chains; achieve process efficiency; automate and integrate back office systems to achieve seamless purchase and accounting efficiency. In this quadrant, power is with the buyer. The use of an e-market increases the potential buying power of the buyers. The sellers could end up incurring costs while upgrading systems and integrating with buyer backend systems. Implications for the e-marketplace are that there could be a large number of suppliers selling commodity items with high supply costs relative to the value of the items.

\subsection{Longer Term Relationship Quadrant (one buyer, one seller)}

The Longer Term Relationship Quadrant is appropriate for items requiring a high degree of planning between buyers and sellers either in the design stage or in fulfillment, typically strategic items. The importance of planning can be either due to technical complexity or demand characteristics driven by a time or phased requirement.

The value proposition for buyers and sellers is that concurrent design leads to reduced cycle time and improved manufacturability because the suppliers are part of the buyer's supply chain. Supply chain integration between buyers and sellers also improves customer service. Strategic relationships lead to few buyers and sellers, which can result in improved service, and reduced risks due to immature technical solutions. This was needed at BHP for the procurement of many contracted items such as critical expensive capital items. E-marketplace exchange enables the procurement of customised engineering and capital equipment from a small number of specialised suppliers, and sourcing of products where supply assurance may be more important than price. Because these are often high value low volume items, the role of e-markets in the transactions is likely to be less, as the transactions are often made on the basis of one-to-one. However, where there are a number of large buyers who can agree on timing and product, buyers may be able to exert buying power even though the relationship becomes one-to-one on contract signature. 


\subsection{Seller Quadrant (few sellers, many buyers)}

The Seller Quadrant is appropriate for situations where the supplier hosts differentiated or value added products, often on its own Web site. The product for sale is not a commodity, and the seller is a monopoly or differentiated oligopoly of the product. Buyers are forced to buy from a limited number of suppliers. At BHP, this was included because BHP wished to test e-procurement processes on the sell side or customer side. BHP tried the sale of guaranteed quality diamonds from its Ekati mine, and some resources which were differentiated on the basis of their chemical composition.

The value proposition in this quadrant is that the seller aims for monopoly/oligopoly advantage through ownership of a differentiated product. The buyers have but one or a few suppliers, e-markets or ecatalogues to procure from, with facilities often provided by the supplier. Buyers/customers may be faced with the costs of integrating their technologies with the seller's web site or back office MRP/ERP/legacy systems, or accepting seller technological assistance in servicing the transactions. The supplier has marketplace power.

\subsection{E-Enabled Supply Chain/Value Chain Logistics}

Supply chain management is the coordination of material, information and financial flows between and among all the participating parties (Kalakota and Robinson 2000). It is an important entity of e-procurement for timely acquisition of goods and services. Logistics is common across all business buy, do (manage) and sell functions. With the advent of ecommerce, traditional logistics is being radically transformed to meet the demands of agile, high-velocity, granular approach (Bayles, 2001). There are two main components to e-enabled logistics. These are the supply chain itself, and the e-enablement of logistics. E-enablement of supply chains may lead to disintermediation, reintermediation, or infomediation of some businesses in the supply chain, based on the contribution of the participants in the chain. The three alternatives for such arrangements are that the buyer can reach back or the manufacturer can reach forward, or a new intermediary such as an e-market can add new value.

On both the sell side and the buy side, it is necessary to provide an underpinning delivery service. To deliver within a specified time frame and to have a returns policy, there is a need to process each web placed order for personalisation, to track the order status, and to keep the customer informed. Organisations with logistics services already in place will have an advantage, since logistics may well become a new 'core' business within the 
e-enabled company. E-enabled supply chain logistics fulfilment options include insourcing, outsourcing and virtual warehousing through suppliers. Logistics e-fulfilment requires a high degree of flexibility in infrastructure, people, and IT skills to adjust to various product mixes and unpredictable demand patterns. Whether e-fulfilment logistics is in-house, outsourced or virtual, costs of technology upgrades, re-engineered business process and an infrastructure to support logistics has to be put in place to attain efficiencies. Disintermediation of intermediaries is an increased possibility when using esupply arrangements, because the buyer can more easily go 'global' to the supplier manufacturers more easily.

\subsection{E-Enabled Acquisition And Procure To Pay Processes.}

The technological infrastructure of the procure-to-pay and back office processes of the supplier, buyer and e-marketplaces may be one of the major barriers to e-procurement, together with the availability and training of the staff to operate the new systems successfully. E-enabled logistics order fulfilment process starts once the on-line customer clicks the 'buy' option. It is then the responsibility of an order management logistics system to confirm inventory availability, manage each item, make delivery arrangements, and track the order through its lifecycle to completion on confirmation of its delivery by the carrier. This integration is not easy to achieve.

\section{APPLICATION OF THE MODEL AND FINDINGS}

During 2000/2001, the proposed model was implemented at BHP to eenable the procurement processes. The outcome of the application of the model is discussed in the following sections.

\subsection{Marketplace Quadrant - Product: Photocopy Paper.}

\begin{tabular}{|l|l|}
\hline Participants & $\begin{array}{l}\text { 'horizontal' e-marketplace } \\
\text { CorProcure. Participant buyers were the } \\
14 \text { major Australia-based corporate founding shareholders of } \\
\text { corProcure, } \\
\text { suppliers were major Australia-based paper suppliers; reverse } \\
\text { auction engine was provided by Price Waterhouse Coopers(PwC) }\end{array}$ \\
\hline
\end{tabular}




\begin{tabular}{|l|l|}
\hline $\begin{array}{l}\text { E-Exchange } \\
\text { Conditions }\end{array}$ & $\begin{array}{l}\text { Specific time, date, \& payment in AU\$, Delivery facilitated by } \\
\text { corProcure, with PwC the contracted } \\
\text { reverse auction engine agent; Request for Quotation and } \\
\text { Specification issued prior to auction after considerable discussion } \\
\text { and meetings by corProcure and PwC with buyers and suppliers; } \\
\text { corProcure set a very low reserve price for the auction which was } \\
\text { based on a knowledge of the current supplier's prices provided by } \\
\text { current buyers. }\end{array}$ \\
\hline Expected Outcome & $\begin{array}{l}\text { Reduced up front costs for buyers and suppliers, online e- } \\
\text { catalogues provided by suppliers which could be compared, e- } \\
\text { search facilities, e-ordering, approval and payment, Reduced } \\
\text { inventory for buyers and suppliers, possible disintermediation of } \\
\text { some paper distributors }\end{array}$ \\
\hline Actual Outcome & $\begin{array}{l}\text { No bids were made by any supplier. } \\
\text { Issues }\end{array}$ \\
$\begin{array}{l}\text { Selection of this apparently 'easy' commodity may not have been } \\
\text { the best choice in retrospect; } \\
\text { Existing relationships between buyers and suppliers and the supply } \\
\text { chain proved difficult to break; } \\
\text { The new unproven method of e-procurement was another issue. }\end{array}$ \\
\hline
\end{tabular}

Table 2.

\subsubsection{Discussion.}

The failure by the e-market corProcure to successfully orchestrate this reverse auction was due to a number of factors including supplier lack of knowledge of or confidence in the new e-procurement processes, supplier lack of trust in reverse auctions; supplier concern about e-payment processes not being in place and difficult/costly to get the required technology and trained people into place; supplier preferment of existing buyer/supplier contracts and the difficulties associated with existing contract end dates to be matched to new contract start dates; draconian terms and conditions of the contract by the e-market and its consultant on behalf of the buyers (or an anticipation that this was the collective buyer's requirement); supplier's very low margins on A4 paper meant possibly an unrealistic reserve price was set for the reverse auction. Because this commodity was often used by suppliers as a 'loss leader' for other of their stationery products, suppliers may have hesitated to bid in an auction which would have split the paper away from the other stationery items being sold at much higher margins as part of an overall deal with a buyer; there was a concern that the paper ordered in such 
large quantities in such a short time period could not be matched by the Australia based manufacturers.

corProcure was an open independent regional internet based procurement marketplace for buying and selling indirect goods and services. It was a horizontal exchange business which was established by Amcor, AMP, ANZ, Australia Post, BHP, Coca-Cola Amatil, Coles Myer, Fosters, Goodman Fielder, Orica, Pacific Dunlop, Qantas, Telstra and Wesfarmers to create a B2B web based buying and selling exchange for indirect goods. CorProcure's plan was to use technology to seamlessly connect buying and supplying trading partners in order to extract maximum value from the supply chain for all participants.

The existing A4 paper supply chain arrangements were not disintermediated into the potential e-supply chain, as anticipated by some of the buyers and suppliers (Figure 5).

\section{Current Supply Chain Model:}

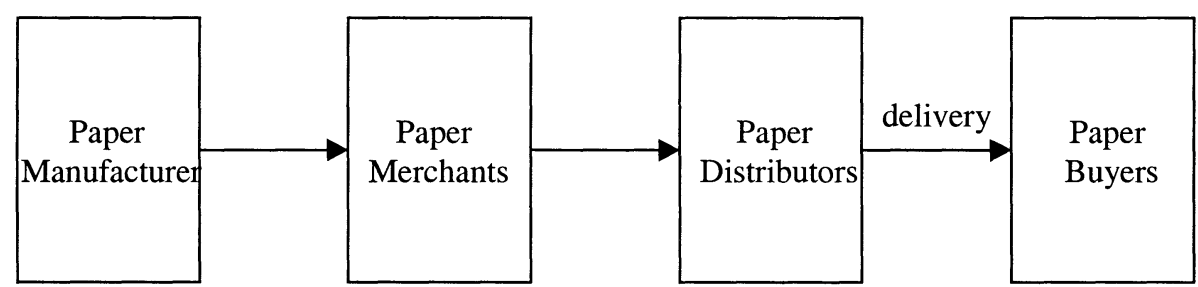

\section{e-Supply Chain Model:}

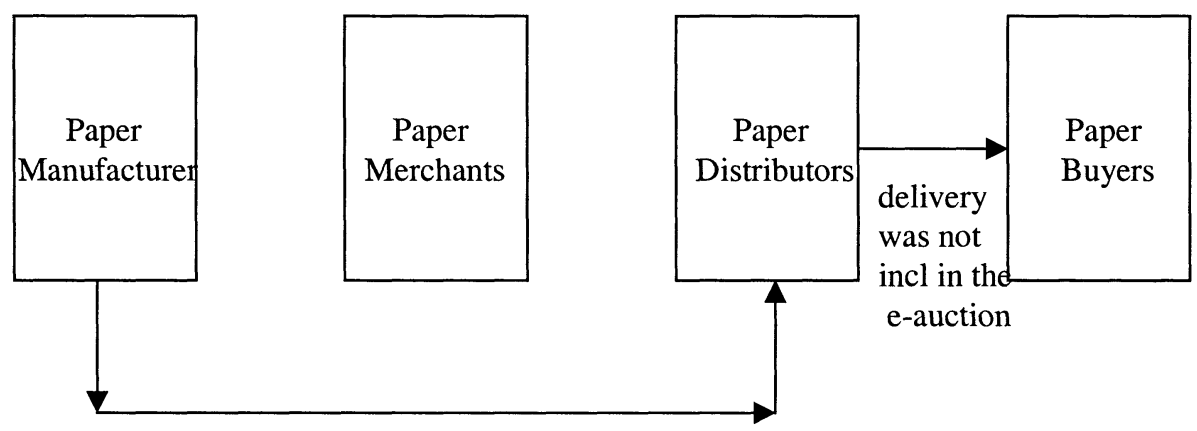

Figure 5. Current and Potential e-Supply Chains 
The Australian consumer watchdog (ACCC) was kept informed about the proposed auction by the e-market corProcure, but did not become involved because the amount of paper being auctioned was a very small part of the total Australian marketplace in A4 paper. However, conditions set by the ACCC concerning marketplace collusion by buyers or sellers were met. The corProcure e-market trial was perhaps premature. In retrospect, selection of A4 paper may not have been a good choice because it tended to be one part of an overall value chain/supply chain process and supplier marketing strategy. The e-market found it difficult to develop a strategy around these issues, transaction technology was not in place connecting the e-market and all participating buyers and sellers. The e-market failed to provide a value proposition either for itself or for the suppliers involved. In so doing, it failed to provide a value proposition for the buyers or its founding shareholders. The e-market corProcure has subsequently been purchased by one of its founding shareholders, Australia Post, in December 2001.

\subsection{Buyer Quadrant - Product: Hotel Rooms and Services.}

\begin{tabular}{|l|l|}
\hline Participants & $\begin{array}{l}\text { One multinational corporate buyer; reverse auction agent } \\
\text { FreeMarkets@; many (50-55)***,****,***** star hotel room } \\
\text { suppliers in Sydney and Melbourne. }\end{array}$ \\
\hline $\begin{array}{l}\text { E-Exchange } \\
\text { Conditions }\end{array}$ & $\begin{array}{l}\text { Facilitated by reverse auction agent FreeMarkets@ operating from } \\
\text { Pittsburg USA \&Aust, Request For Quotation \& Information } \\
\text { available to suppliers online 1 week in advance; FreeMarkets } \odot \\
\text { detailed market analysis took 4 weeks; FreeMarkets } \odot \text { interviews } \\
\text { with both suppliers and buyer; FreeMarkets@ } \odot \text { thorough training of } \\
\text { buyer and suppliers in the e-marketplace reverse auction process. }\end{array}$ \\
\hline Expected Outcome & $\begin{array}{l}\text { Cost and time savings; } \\
\text { Better value for money while retaining the same quality of hotel } \\
\text { accommodation for employees; improved budgetary control; } \\
\text { improvements in information flow between buyer and seller; } \\
\text { reduced maverick buying; improved payment processes; enhanced } \\
\text { relationships between buyer and suppliers. }\end{array}$ \\
\hline Actual Outcome & $\begin{array}{l}\text { Very successful outcome facilitated by professional e-market } \\
\text { reverse auction agent (FreeMarkets@); }\end{array}$ \\
\hline
\end{tabular}




\begin{tabular}{|l|l|}
\hline Issues & $\begin{array}{l}\text { Technology and training of suppliers and buyers; business model; } \\
\text { Demonstration of benefits by reverse auction agent to buyers and } \\
\text { suppliers; value proposition for all; trust established by all in the } \\
\text { process and in the reverse auction agent. }\end{array}$ \\
\hline
\end{tabular}

Table 3 .

\subsubsection{Discussion}

Benefits to BHP included e-procurement delivery process cost and time savings. These were each estimated at around one third to one fifth of the traditional procurement process. Overall contract savings achieved were around $12.5 \%$ of the value of the contract sum, in a market not expected to show any savings at all. Figure 6 indicates the outline reverse auction process:

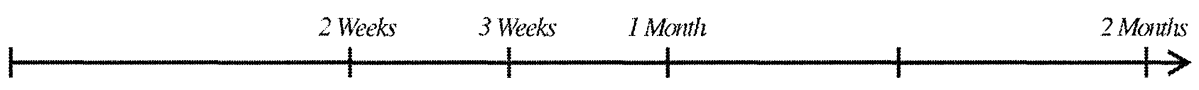

FreeMarkets Online Bidding Process
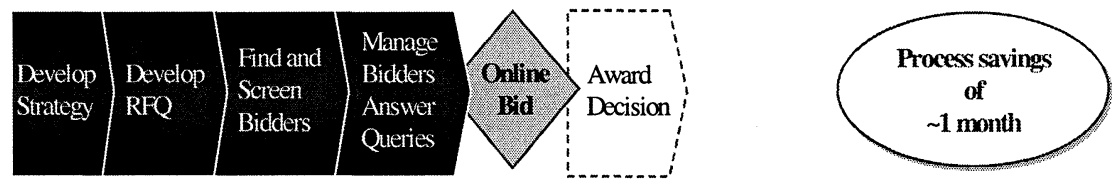

Traditional Process

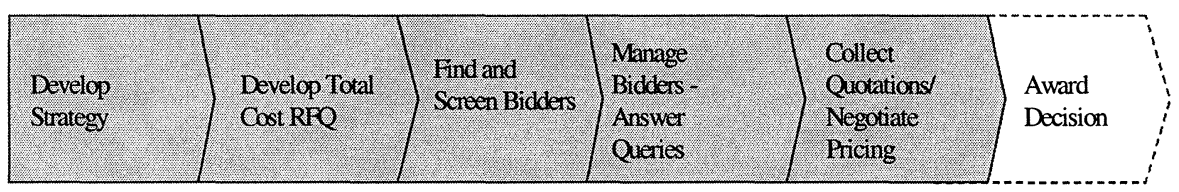

Figure 6. Freemarkets Online Bidding Process versus Traditional Process-Time Savings

Because the selected suppliers were to be listed and BHP employees allowed to use these suppliers only, maverick or off the list buying by BHP employees reduced to almost zero. Since the number of suppliers awarded 
contracts and able to be used by employees was significantly reduced from previous, payment processes for both suppliers and buyer were expected to be improved. Contract award was made on the basis of 'value for money', not simply 'lowest price'. This was achieved by FreeMarkets@ finding out the most used services by the buyer's employees and setting a percentage of the room rate for the supply of these services. When the reverse auction had closed, the buyer assessed the bids made. After discussion with the lowest several bidders of each 'event', the buyer awarded contracts for a specified guaranteed number of 'room nights per annum' to the 'best value for money' bidders. Because there were two or three bidders awarded contracts for each level of hotel or 'event', competition between these suppliers for the guaranteed number of rooms per annum was expected to continue over the 12-month life of the contract. Previous well performing suppliers were awarded for their service because the buyer awarded contracts to a number of these suppliers despite the fact that they did not necessarily bid the lowest hotel room rate. Relationships between the buyer and suppliers were based on trust, established during the pre-auction period. No 'dummy' auction bids were permitted, and all suppliers could see on their screens what bids were being made at what time. No supplier knew which bidder made which bid, and the auction was continuously extended by a minute if a bid was made within the last minute. The whole auction took only a few hours. It was an open and transparent bid process, bound legally at the end of each 'event' auction by the reverse auction agent contacting the lowest bidders directly to confirm their bid and record the transaction as legally binding. There was equality and equity of bidding arrangements for all suppliers, and no difficulty in obtaining supplier interest. This was a great success. The value proposition for both buyer and sellers could be clearly demonstrated by the e-market reverse auction agent, and the latter achieved a value proposition for itself.

\subsection{Seller Quadrant - Product: Diamonds.}

\begin{tabular}{|l|l|}
\hline Participants & $\begin{array}{l}\text { Seller BHP ‘Aurias' diamonds strongly marketed to marketplace } \\
\text { buyers/customers to e-procure differentiated diamonds over the } \\
\text { web from its web site }\end{array}$ \\
\hline $\begin{array}{l}\text { E-Exchange } \\
\text { Conditions }\end{array}$ & $\begin{array}{l}\text { Specific BHP 'Aurias' web site set up, with diamond inventory and } \\
\text { price available to buyers; each diamond differentiated by a } \\
\text { guarantee and quality certificate }\end{array}$ \\
\hline
\end{tabular}




\begin{tabular}{|c|c|}
\hline Possible Outcomes & $\begin{array}{l}\text { Anticipated possible disintermediation of some distributors, } \\
\text { wholesalers or retailers; consumers drawn to site and transaction as } \\
\text { a result of heavy marketing and promotions, and cost reduction for } \\
\text { buyers by buying direct 'from mine to you'. Seller BHP 'Aurias' } \\
\text { wanted to gain marketing, branding and sales e-experience through } \\
\text { a 'proof of concept' approach. }\end{array}$ \\
\hline Actual Outcomes & Partial success \\
\hline Issues & $\begin{array}{l}\text { Security; } \\
\text { Product emotional and relationship value to customer; special } \\
\text { product characteristics such as 'touchy feely' issues; trust in } \\
\text { process and transaction; technology. }\end{array}$ \\
\hline
\end{tabular}

Table 4.

\subsubsection{Discussion}

In this seller quadrant, the role of BHP and its 'Aurias' diamonds brand was reversed in that BHP was the seller and its customers the buyers. The product selected was a special differentiated product where the seller anticipated a monopoly ie differentiated diamonds through guarantees, quality, and web site sales. While some web site sales were made, buyer /consumer resistance occurred since the product was expensive, buyers wanted to see and assess the goods before buying and committing to transacting large sums of money electronically. There was found to be a strong buyer preference to see and touch the product, rather than buy over the web. From BHP's perspective, there was consideration that some differentiation of the supply chain might occur. Figure 7 indicates the usual diamonds supply/value chain compared to an optimized e-diamonds supply/value chain. The anticipated outcome of this quadrant in the model was to reach the buyers directly, so disinter mediating the middle enterprises and reducing the overall supply costs. 
Usual diamonds supply/value chain:

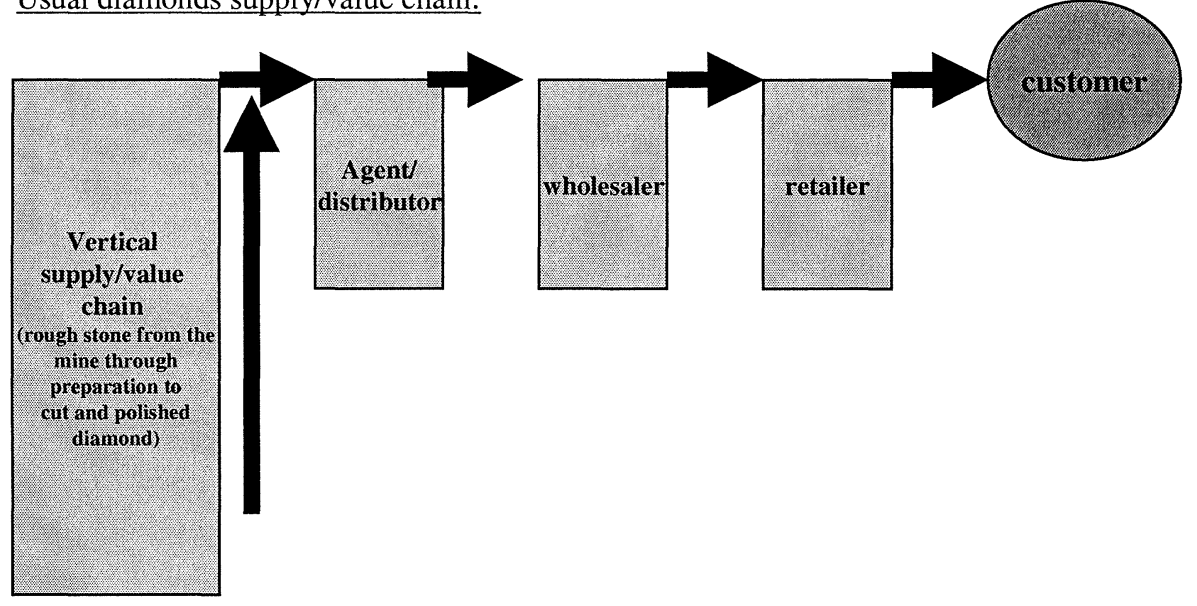

Optimised e-diamonds supply/value chain:

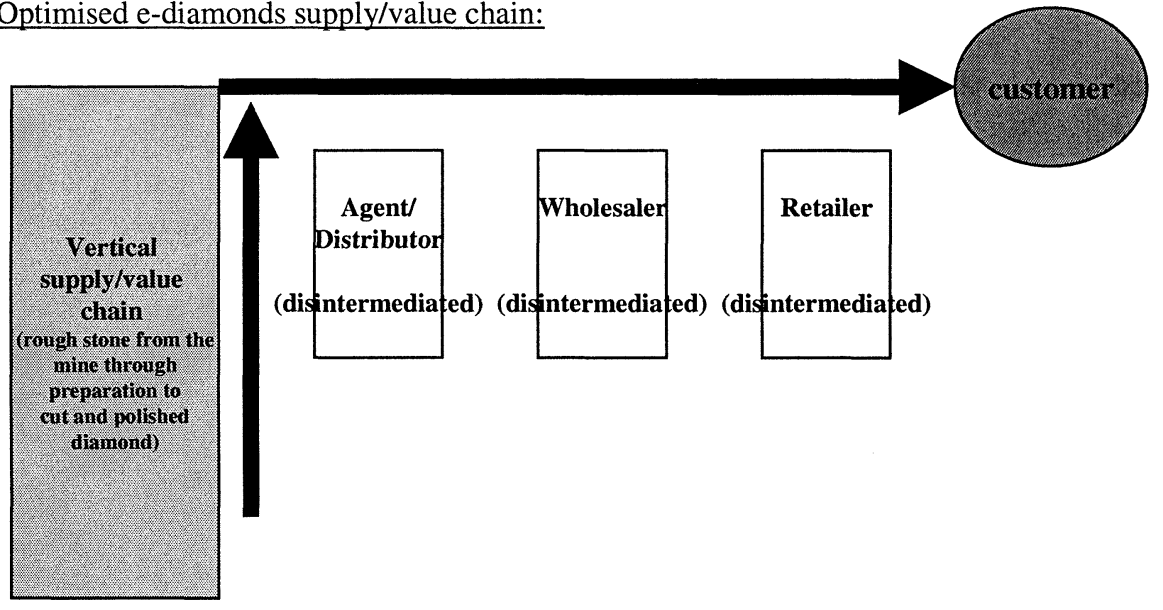

Figure 7. Usual versus Optimized e-Diamonds Supply/Value Chain

While this application was tested with a specific product, the product itself may not have been such a good choice because of its value and special characteristics. However, while this was not immediately successful the seller BHP and its 'Aurias' brand and e-market achieved much e-experience in this 'proof of concept' trial. The business model is being adjusted to go global. 


\subsection{Longer Term Relationship Quadrant - Product: Capital Equipment}

\begin{tabular}{|c|c|}
\hline Participants & $\begin{array}{l}\text { Multinational buyers and sellers of major capital equipment items } \\
\text { ie 'vertical' products. Use of e-market Quadrem }\end{array}$ \\
\hline $\begin{array}{l}\text { E-Exchange } \\
\text { Conditions }\end{array}$ & contracts for few items of high value, using Quadrem \\
\hline $\begin{array}{l}\text { Anticipated } \\
\text { outcomes }\end{array}$ & $\begin{array}{l}\text { Anticipated possible disintermediation of some distributors, } \\
\text { wholesalers or retailers; consumers drawn to site and transaction as } \\
\text { a result of heavy marketing and promotions, and cost reduction for } \\
\text { buyers by buying direct 'from mine to you'. Seller BHP 'Aurias' } \\
\text { wanted to gain marketing, branding and sales e-experience through } \\
\text { a 'proof of concept' approach. }\end{array}$ \\
\hline Actual Outcomes & Partial success, but improving with time \\
\hline Issues & $\begin{array}{l}\text { Major industry items of high value are usually of a strategic nature } \\
\text { with fewer suppliers. This may not be as conducive to an e-market } \\
\text { place based bidding process. However, because of the 'whole of } \\
\text { life' relationship issues of the product, the value of e-markets and } \\
\text { e-procurement lies in the passage of post contract information and } \\
\text { in the pre contract award process. }\end{array}$ \\
\hline
\end{tabular}

Table 5 .

\subsubsection{Discussion}

This quadrant of the model covers major items of capital equipment and strategic industry related products where supply assurance is more important for the buyer than price. The risks for BHP is that a monopoly situation may be set up with specific suppliers so increasing BHP's vulnerability, unless another source of supply is also able to be contracted. However, this is sometimes not possible. BHP is choosing this route with the assistance of the 'vertical' e-market Quadrem. Quadrem aims to reshape procurement for the global mining and metals industry by establishing a B2B internet based marketplace by end 2001. Shareholders are Alcan Aluminium Limited, Alcoa Inc., Anglo American plc, Barrick Gold Corp, BHP, Corporacion Nacional del Cobre de Chile (CODELCO), Companhia Vale do Rio Doce (CVRD), De Beers Consolidated Mines Ltd., Glencore Int AG; Imerys, Inco Limited, MIM Holdings; Newmont Mining Corporation, Noranda Inc., Normandy Mining, Pechiney, Penoles; Phelps Dodge Corporation, Rio 
Tinto, the Votorantim Group, WMC Limited, and Morgan Stanley Dean Witter. With the demise of corProcure, Quadrem is expected to move into much of the horizontal space as well, so providing its shareholders, buyers and suppliers with a complete service.

\section{CONCLUSION}

The model was developed to provide a roadmap and guidance to the eenabling of the procurement process at BHP, an Australian global mining, minerals and metals resources enterprise which has since merged with Billiton. Considerable time and effort was put into the development of the model. It is based on a thorough review of literature on B2B exchanges, is therefore generic and easily applied to different situations, enterprises and environments.

The model highlighted the benefits of e-procurement, the roles of exchange partners and intermediaries. However, each of the four quadrants of the model had differing success in delivering benefits to BHP. This is the subject of further research.

The model did provide a strong, flexible e-procurement framework which can be modified and implemented in the future even though the technology, marketplace environment, and supply/value chains may change.

\section{REFERENCES}

Australian Bureau of Statistics Report 8129.0, 'Business Use of Information Technology', December, 2000.

Bayles, D., 2001, E-Commerce Logistics and Fulfillment, Prentice Hall, New Jersey.

Chaffey, D., 2002, E-Business and E-Commerce Management, Prentice Hall, Great Britain.

Christiaanse, E., Sinneker, R. and Mossinkoff, M., 2001, The Impact of B2B Exchanges on Brick and Mortar Intermediaries: The Elemica Case', $9^{\text {th }}$ European Conference on Information Systems, Bled, Slovenia, June 27 - 29, pp 422 - 432.

Kalakota R. and Robinson M, 2001 'e-Business: Roadmap for Success', Addison -Wesley, Canada.

Kaplan, Steven, Sawhney and Mohanbir, 2000, 'E-Hubs: The New B2B Marketplaces', Harvard Business Review, May/June 2000, Volume 78, Issue 3, pp 97.

Kinney S (2000) 'An Overview of B2B and Purchasing Technology', Freemarkets, Pittsburg, PA.

McGagh J (2000), 'From Vision to Technology to Value', Rio Tinto,

Matthewson, J. A., 2001, 'e-Business a jargon-free practical guide', Butterworth Heineman, Boston;

NOIE Report (2001, 'B2B E-Commerce: Capturing Value Online', Commonwealth of Australia/ 
Rayport, J. and Jaworski, B., 2002, introduction to e-commerce', McGraw-Hill / Irwin MarketspaceU, New York.

Swedish Trade Council www.emarketservices.com/about_emarket_places/main.htm

Thomson,D., 1997, : 'Purchasing Statistics Bulletin 1989/90 to 1995/96', pp7, Department of Defence, Canberra, February

Thomson, D., 2000, A Macro Level Business Model for E-Enabled Procurement, MBA Thesis, Victoria University, Melbourne, Australia.

Thomson, D. and Singh, M., 2001, 'A Macro Level Business Model For E-Enabled Procurement', CollEcTeR Conference, Coffs Harbour, December 3-4. 